Journal of Advanced Research in Fluid Mechanics and Thermal Sciences

Journal homepage: www.akademiabaru.com/arfmts.html ISSN: 2289-7879

\title{
Optimization of $\mathrm{Cu}(\mathrm{II})$ Removal Using Aceh Natural Bentonite, Intercalated Bentonite and Pillared Bentonite Using Box- Behnken Design In Response Surface Methodology
}

\author{
Jakfar $^{1}$, Husni Husin², Abrar Muslim², ${ }^{2}$, Darmadi $^{2}$ \\ Doctoral Program of Engineering, Faculty of Engineering, Universitas Syiah Kuala, Darussalam, Banda Aceh, Indonesia \\ Department of Chemical Engineering, Faculty of Engineering, Universitas Syiah Kuala, Darussalam, Banda Aceh, Indonesia
}

ARTICLE INFO ABSTRACT

\section{Article history:}

Received 3 May 2020

Received in revised form 8 June 2020

Accepted 8 June 2020

Available online 5 July 2020

\begin{abstract}
Optimization of the $\mathrm{Cu}(\mathrm{II})$ removal by natural bentonite from Aceh through modification with $\mathrm{NaCl}$ intercalation and pillarization with $\mathrm{AlCl}_{3}$ in aqueous solution was conducted using Response surface methodology (RSM). Batch mode experiments were conducted based on a Box-Behnken Design in the RSM. Adsorption results were investigated as a function of two independent factors i.e. initial $\mathrm{CU}$ (II) ions concentration (100-500 $\mathrm{mg} / \mathrm{L}$ ) and agitation time (30-120 min), bentonite mass of (2 g). The results of analysis of variance were obtained viz. the influence of the two independent variables viz. initial copper concentration and agitation time are very significant. Optimization equation were obtained for natural bentonite (NB), intercalated bentonite (IB) and pillared bentoned (PB). The optimization conditions for copper removal were obtained at $300 \mathrm{mg} / \mathrm{L}$ initial copper concentrations and 75.901 min of agitation times. The maximum $\mathrm{Cu}(\mathrm{II})$ adsorption capacity of the NB, IB and PB were $27.101,27.568$ and $28.969 \mathrm{mg} / \mathrm{g}$ respectively.
\end{abstract}

Keywords:

Adsorption; Bentonite; Optimization;

Response surface Methodology

Copyright $@ 2020$ PENERBIT AKADEMIA BARU - All rights reserved

\section{Introduction}

Heavy metal which is not easy biodegradable pollutant might release from industrial practices [12]. Among heavy metal, copper can threat human health in excessive amount causing tissues and organs malfunction such as stomach distress and kidney damage. It can cause anemia and death [35]. Copper may be found in many industrial waste such as mining practices, smelting and electroplating, steel and fertilizer industries, circuit wires and chemical reagents production [6-9].

There are several methods developed for removing heavy metal ions from wastewater before disposal, which are bioremediation [10], neutralization using chemicals [11], nano hollow sphere-

\footnotetext{
* Corresponding author.

E-mail address: abrar.muslim@che.unsyiah.ac.id
}

https://doi.org/10.37934/arfmts.73.1.167177 
based separation [12] and photocatalytic oxidation [13]. Adsorption is the better one because it is an inexpensive and simple process and less energy use [14-15].

Natural bentonite has different adsorption according to its composition and mineral content of the impurities, therefore it needs to be purified and modified so as to increase its adsorption [16-17]. Likes natural zeolite, natural bentonite was chosen as a raw material of adsorbent because it has several advantages, among others, namely as excellent material, chemically stable, heat resistant [18], and easily intercalated and pillared with other elements or chemical compounds [19-20]. This modification method of natural bentonite was applied tartrazine removal [21], adsorption of bisphenol [22] and cobalt(II) [23] and phosphate from aqueous solution [24]. Unfortunately, there is limited number of studies proposing intercalated and pillared bentonite using Indonesian and even Acehnese natural bentonite for copper removal. Meanwhile, intercalated and pillared bentonite have high surface area for surfactants and phenol adsorption [25-26]. Interestingly, Indonesia has an abundant natural bentonite which is approximately 380 million tons, and Aceh is expected to have approximately 2.6 million tons [27]. The use of intercalated and pillared Acehnese bentonite would be an innovative adsorbent for copper removal.

Wastewater treatment process is not suitable with the classical method because it requires a lot of time, unreliable and inflexible. Response surface methodology (RSM) is very efficient design and widely used technique, can be adapted for parameters optimization of various wastewater treatment processes [28-29]. RSM is better alternative is used because it includes the influences of individual factors as well as the influences of their interaction. Box-Behnken design in the RSM is a technique for designing experiments, evaluating the effects of several factors, and achieving the optimum conditions for desirable responses with a limited number of planned experiments [30-32]. Therefore, optimization of $\mathrm{CU}(\mathrm{II})$ removal using intercalated and pillared Acehnese bentonite based BoxBehnken design in the RSM would be the novel of current study.

Current study proposed preparation of intercalated and pillared Aceh natural bentonite for the removal of $\mathrm{Cu}$ (II) from aqueous solution. Natural bentonite was modified through intercalate Na ions using $\mathrm{NaCl}$ and pillared $\mathrm{Al}$ ions using $\mathrm{AlCl}_{3}$. The objective of this research was to study the effect of initial $\mathrm{Cu}(\mathrm{II})$ ions concentration and agitation time on adsorption of $\mathrm{Cu}(\mathrm{II})$ using Aceh natural bentonite and intercalated and pillared Aceh natural bentonite. The optimum conditions of $\mathrm{Cu}(\mathrm{II})$ removal was determined using Box-Behnken design in the RSM under Design Expert software.

\section{Materials and Experimental Procedure}

\subsection{Natural Bentonite (NB)}

Natural bentonite was obtained from Cot Mambo Village, Nisam Sub-district, North Aceh District, Aceh Province, Indonesia. In the first utilization step of natural bentonite, natural bentonite of $25 \mathrm{~g}$ was grinded using ball mill and sieved to get a size of 180-200 mesh. Then the mixed solution is separated by decantation, afterwards the bentonite was heated at $105^{\circ} \mathrm{C}$ for two hours and saved in desiccator. Bentonite after sifting and heating was spread in a solution $500 \mathrm{ml}$ buffer acetate at $\mathrm{pH}$ 4,8 and stirred for 5 hours until no $\mathrm{CO}_{2(\mathrm{~g})}$ was formed. Then, mixture was separated using centrifuge tub. Bentonite deposits was dried at $105^{\circ} \mathrm{C}$ using an oven. After drying, it was leaved in the oven until reaching at $27^{\circ} \mathrm{C}$ and then it were stored in a bottle for $\mathrm{Cu}(\mathrm{II})$ adsorption experiments. 


\subsection{Intercalated Bentonite (IB)}

Purified natural bentonite of $25 \mathrm{~g}$ was mashed to get a size of 180-200 and then it was inserted into $500 \mathrm{ml} \mathrm{M} \mathrm{NaCl}$. The mixture was stirred using a magnetic stirrer for 24 hours at $70^{\circ} \mathrm{C}$. The mixture was separated by decantation, and the precipitate was washed with aqubides to remove residual chloride ions. The filtrate from leaching sludge was tested with $1 \mathrm{M} \mathrm{AgNO}_{3}$ solution until there was no $\mathrm{AgCl}$ white precipitate was formed. Bentonite deposits that free from $\mathrm{Cl}^{-}$ions was dried at $105^{\circ} \mathrm{C}$.

\subsection{Pillared Bentonite (IB)}

Aluminium polication solution was prepared by adding $660 \mathrm{ml}$ of $0.2 \mathrm{M} \mathrm{NaOH}$ solution slowly to $300 \mathrm{ml} \mathrm{AlCl}_{3} 0,1 \mathrm{M}$ solution with the $\mathrm{OH} / \mathrm{Al}$ volume ratio of 2.2 and it was stirred for up to 48 hours. Preparation of intercalated bentonite suspension was carry out by weighing $3.333 \mathrm{~g}$ of intercalated bentonite, dissolved it in $166.7 \mathrm{ml}$ of water to obtain $2 \%$ suspension, and it was stirred for 1 hour. The result obtained in the preparation of Al polycation solution were taken as much as $960 \mathrm{ml}$ and added simultaneously slowly into $2 \%$ intercalated bentonite suspension and stirred for 24 hours at room temperature. Then, the precipitate was washed with aqubides to remove chloride ions and tested with $\mathrm{AgNO}_{3}$ until no precipitate was formed. The precipitate was dried at $40^{\circ} \mathrm{C}$ for 3 days. Then, it was heated to $300^{\circ} \mathrm{C}$ for 5 hours. The results were analyzed by testing adsorption of $\mathrm{Cu}(\mathrm{II})$ ions by AAS.

\subsection{Experimental Design}

The statistical design of experiments is an efficient procedure for planning experiment so that the data obtained was analyzed to yield valid and objective conclusions. The two main applications of experimental design were screened, in which the factors that influence the experiment were identified and optimized, in which the optimal setting or conditions for an experiment can be found [21, 22]. Design Expert 12 (Stat-Ease Inc., Minneapolis, MN, USA) software used for regression and graphical analysis of obtained data. Box-Behnken design was used under the RSM design. In order to achieve optimum $\mathrm{Cu}(\mathrm{II})$ removal, the RSM experimental was used to study response pattern and to determine the best combination of variables which gave the optimum condition for the experiment. In this research, two variables $X_{1}$ (initial copper concentration) and $X_{2}$ (agitation time) were used. An experimental design for Aceh natural bentonite, intercalated bentonite and pillared bentonite as adsorbents are shown in Table 1. Batch mode of $\mathrm{Cu}(\mathrm{II})$ adsorption experiments were carried out with adsorption systems consisting $2 \mathrm{~g}$ of adsorbent, $200 \mathrm{~mL} \mathrm{Cu}$ (II) ions in solution and stirred at 100-rpm, $27^{\circ} \mathrm{C}\left( \pm 1^{\circ} \mathrm{C}\right)$ and $1 \mathrm{~atm}$. 
Table 1

Design and analysis experiment

\begin{tabular}{|c|c|c|c|c|c|}
\hline Run & $\begin{array}{l}\text { Factor } 1 \\
X_{1} \\
(\mathrm{mg} / \mathrm{L})\end{array}$ & $\begin{array}{l}\text { Factor } 2 \\
X_{2} \\
(\min )\end{array}$ & $\begin{array}{l}\text { Response } 1 \\
Y_{1} \\
(\mathrm{mg} / \mathrm{L})\end{array}$ & $\begin{array}{l}\text { Response } 2 \\
Y_{2} \\
(\mathrm{mg} / \mathrm{L})\end{array}$ & $\begin{array}{l}\text { Response } 3 \\
Y_{3} \\
(\mathrm{mg} / \mathrm{L})\end{array}$ \\
\hline 1 & 300 & 75 & 275.532 & 280.351 & 290.211 \\
\hline 2 & 300 & 130 & 296.234 & 298.234 & 299.511 \\
\hline 3 & 300 & 75 & 275.532 & 280.351 & 290.211 \\
\hline 4 & 100 & 30 & 40.322 & 40.322 & 40.500 \\
\hline 5 & 500 & 75 & 300.321 & 304.234 & 310.211 \\
\hline 6 & 500 & 30 & 60.231 & 61.547 & 65.212 \\
\hline 7 & 300 & 75 & 275.532 & 280.351 & 290.211 \\
\hline 8 & 100 & 120 & 95.251 & 96.131 & 98.430 \\
\hline 9 & 300 & 75 & 275.532 & 280.351 & 290.211 \\
\hline 10 & 100 & 75 & 60.431 & 61.671 & 63.912 \\
\hline 11 & 300 & 75 & 275.532 & 280.351 & 290.211 \\
\hline 12 & 300 & 30 & 50.673 & 52.120 & 53.0321 \\
\hline 13 & 500 & 120 & 300.573 & 303.211 & 97.202 \\
\hline
\end{tabular}

Information: $X_{1}=$ initial $\mathrm{Cu}(\mathrm{II})$ ions concentration; $X_{2}=$ stirring time; $Y_{1}$ : the NB adsorption response, $Y_{2}$ : the IB adsorption response, $Y_{3}$ : the $\mathrm{PB}$ adsorption response

For statistical analysis, relationship between the coded and the actual variables can be expressed as Eq. (1).

$x_{i}=\left(\frac{X_{1}-X_{2}}{\Delta X}\right)$

where $x_{\mathrm{i}}$ is independent variable or the dimensionless value of the $\mathrm{i}^{\text {th }}$ independent variable, $X_{1}$ is independent real value, $X_{2}$ is independent real value on the centre point and $\Delta X$ is the step change value. The removal of copper is taken as the dependent variable or response. The behaviour of system is explained by the following of system is explained by the following second-order polynomial model Eq. (2).

$Y=\beta_{0}+\sum_{i=1}^{k} \beta_{i} x_{i}+\sum_{i=1}^{k} \beta_{i i} x_{i}^{2}+\sum_{i=1}^{k} \sum_{j=1}^{k} \beta_{i j} x_{i} x_{j}+\varepsilon$

where $Y$ is predicted response of copper removal in solution, $x_{i}, x_{j}, \ldots, x_{\mathrm{k}}$ are the input variables, which affect the response $Y, x_{i}{ }^{2}, x_{j}{ }^{2}, \ldots, x_{\mathrm{k}}{ }^{2}$ are the square effects, $x_{i} x_{j}, x_{i} x_{\mathrm{k}}$ and $x_{j} x_{\mathrm{k}}$ are the interaction effects, $\beta o$ is the intercept term, $\beta_{i}(i=1,2, \ldots, k)$ is the linier effect, $\quad \beta_{i i}(i=1,2, \ldots, k)$ is the square effect, $\beta_{i j}(i=1,2, \ldots, k ; j=1,2, \ldots, k)$ is the interaction effect and is random error $[17,21,22]$. For this research, Eq. (2) can be written as Eq. (3).

$$
Y_{i}=\beta_{0}+\beta_{1} x_{1}+\beta_{2} x_{2}+\beta_{11} x_{1}^{2}+\beta_{22} x_{2}^{2}+\beta_{12} x_{1} x_{2}
$$




\section{Results and discussion}

\subsection{ANOVA in the regression model}

The data in Table 1 was taken into account for ANOVA and multiple regression analysis in BoxBehnken design using polynomial model Eq. (3). The results are shown in Tables 2, 3 and 4.

Table 2

The NB Analysis of variance

\begin{tabular}{llllll}
\hline Source & SS & DF & MS & F-value & Prob $>$ F \\
\hline Model & $1.45 \mathrm{E}+005$ & 5 & $2.90 \mathrm{E}+004$ & 19.0 & 0.000609 \\
$X_{1}$ & $3.61 \mathrm{E}+004$ & 1 & $3.61 \mathrm{E}+004$ & 23.6 & 0.00184 \\
$X_{2}$ & $5.53 \mathrm{E}+004$ & 1 & $5.53 \mathrm{E}+004$ & 36.2 & 0.000534 \\
$X_{1}{ }^{2}$ & $1.81 \mathrm{E}+004$ & 1 & $1.81 \mathrm{E}+004$ & 11.9 & 0.0108 \\
$X_{2}{ }^{2}$ & $1.89 \mathrm{E}+004$ & 1 & $1.89 \mathrm{E}+004$ & 12.4 & 0.00976 \\
$X_{1} X_{2}$ & $8.59 \mathrm{E}+003$ & 1 & $8.59 \mathrm{E}+003$ & 5.62 & 0.0495 \\
Residual & $1.07 \mathrm{E}+004$ & 7 & $1.53 \mathrm{E}+003$ & - & - \\
\hline
\end{tabular}

Table 3

The IB Analysis of variance

\begin{tabular}{llllll}
\hline Source & SS & DF & MS & F-value & Prob $>$ F \\
\hline Model & $1.49 \mathrm{E}+005$ & 5 & $2.98 \mathrm{E}+004$ & 19.1 & 0.000594 \\
$X_{1}$ & $3.70 \mathrm{E}+004$ & 1 & $3.70 \mathrm{E}+004$ & 23.7 & 0.00182 \\
$X_{2}$ & $5,61 \mathrm{E}+004$ & 1 & $5,61 \mathrm{E}+004$ & 36.0 & 0.000542 \\
$X_{1}{ }^{2}$ & $1.89 \mathrm{E}+004$ & 1 & $1.89 \mathrm{E}+004$ & 12.1 & 0.0102 \\
$X_{2}{ }^{2}$ & $1.99 \mathrm{E}+004$ & 1 & $1.99 \mathrm{E}+004$ & 12.8 & 0.00904 \\
$X_{1} X_{2}$ & $8,64 \mathrm{E}+003$ & 1 & $8,64 \mathrm{E}+003$ & 5.54 & 0.0508 \\
Residual & $1.09 \mathrm{E}+004$ & 7 & $1.56+003$ & - & - \\
\hline
\end{tabular}

Table 4

The PB Analysis of variance

\begin{tabular}{llllll}
\hline Source & SS & DF & MS & F-value & Prob $>F$ \\
\hline Model & $1.57+005$ & 5 & $3.13 \mathrm{E}+004$ & 19.9 & 0.000519 \\
$X_{1}$ & $3.89 \mathrm{E}+005$ & 1 & $3.89 \mathrm{E}+005$ & 24.7 & 0.00161 \\
$X_{2}$ & $5.71 \mathrm{E}+004$ & 1 & $5.71 \mathrm{E}+004$ & 36.4 & 0.000526 \\
$X_{1}{ }^{2}$ & $2.03 \mathrm{E}+004$ & 1 & $2.03 \mathrm{E}+004$ & 12.9 & 0.00883 \\
$X_{2}{ }^{2}$ & $2.23 \mathrm{E}+004$ & 1 & $2.23 \mathrm{E}+004$ & 14.2 & 0.00702 \\
$X_{1} X_{2}$ & $8.76 \mathrm{E}+003$ & 1 & $8.76 \mathrm{E}+003$ & 5.58 & 0.0502 \\
Residual & $1.10 \mathrm{E}+004$ & 7 & $1.57 \mathrm{E}+003$ & - & - \\
\hline
\end{tabular}

Note: $X_{1}=$ initial $\mathrm{Cu}(\mathrm{II})$ ions concentration; $X_{2}=$ stirring time; $\mathrm{SS}=$ sum of squares; $\mathrm{DF}=$ degree of freedom; $\mathrm{MS}=$ mean square

Analysis of variance (ANOVA) for responses (NB), (IB), and (PB) indicate that effect of individual factors, interaction factors for degree of confidence $\geq 95 \%$. The RSM model is selected quadratic model, $\mathrm{R}^{2}=0.93, \mathrm{CV}=19.1$, and the model is very significant.

\subsection{Fitting model}

Analysis of variance (ANOVA) were used to evaluate effect of individual factors, interaction factors, and multiple regression analysis in Design Expert 12. Box-Behnken Design in the RSM was used. The model equation which are used to predict the optimum degree of $\mathrm{Cu}$ (II) removal were determined by multiple regression analysis using following equations. 
The NB final equation in terms of actual factors is shown by Eq. (4).

$Y_{1}=-263+1.17 X_{1}+5.89 X_{2}-0.00195 X_{1}^{2}-0.0357 X_{2}^{2}+0.00515 X_{1} X_{2}$

The IB final equation in terms of actual factors is shown by Eq. (5).

$Y_{2}=-270+1.20 X_{1}+6.04 X_{2}-0.00200 X_{1}^{2}-0.0367 X_{2}^{2}+0.00516 X_{1} X_{2}$

The PB final equation in terms of actual factors is shown by Eq. (6).

$Y_{3}=-270+1.20 X_{1}+6.04 X_{2}-0.002 X_{1}^{2}-0.0367 X_{2}^{2}+0.00516 X_{1} X_{2}$

where $Y_{1}$ is the NB predicted response for $\mathrm{Cu}(\mathrm{II})$ ions removal, $Y_{2}$ is the IB response for $\mathrm{Cu}(\mathrm{II})$ ions removal, and $Y_{3}$ is the $\mathrm{PB}$ response for $\mathrm{Cu}(\mathrm{II})$ ions removal. Meanwhile $X_{1}$, and $X_{2}$ are independent variables for initial $\mathrm{Cu}(\mathrm{II})$ ions concentration and agitation time respectively.

Based on the equations it showed that the influence of initial $\mathrm{Cu}(\mathrm{II})$ ions concentrations $\left(\mathrm{X}_{1}\right)$ and stirring time $\left(\mathrm{X}_{2}\right)$ affected the $\mathrm{Cu}(\mathrm{II})$ adsorption by bentonite third for natural bentonite (NB), bentonite intercalation results(IB) and bentonite result of pillarization (PB). These effects can be observed from the intercept and coefficients of the three optimization equations respectively. The level of influence of PB > IB> NB [19-20]. The relationship between the bentonite mass and agitation time on $\mathrm{Cu}(\mathrm{II})$ removal are shown in Figures 1, 2 and 3. The optimization response surface contour and 3-D for desirability ramp plots for the effect initial $\mathrm{Cu}$ (II) ions concentration and agitation time on $\mathrm{Cu}(\mathrm{II})$ removal is clearly shown in Figure 4 . The optimum condition found was a removal system with initial copper concentration of $300 \mathrm{mg} / \mathrm{L}$ and agitation time of $75.901 \mathrm{~min}$ shown by the desirability value of 0.935 .
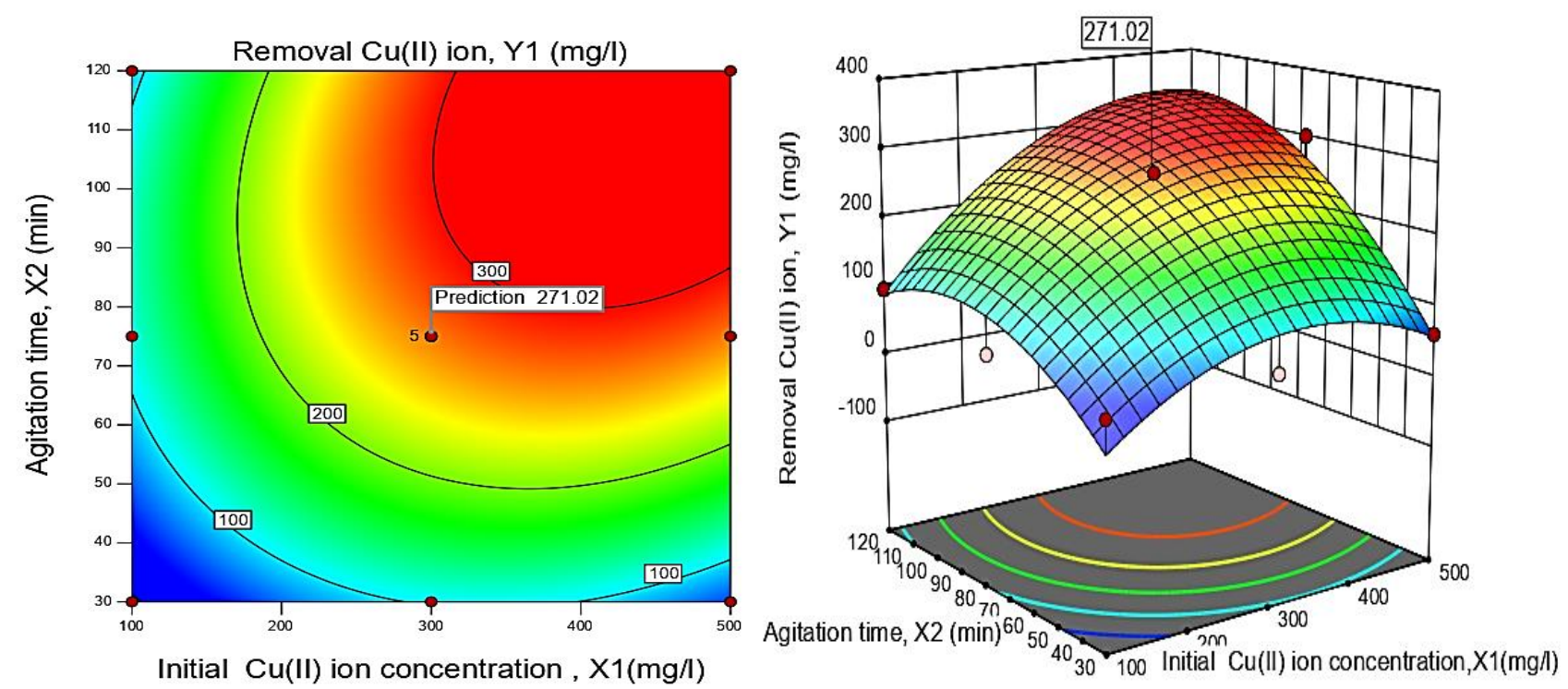

Fig. 1. The NB response surface contour and 3-D plots for the effect of initial $\mathrm{Cu}(\mathrm{II})$ ions concentration and agitation time $(\mathrm{min})$ on $\mathrm{Cu}(\mathrm{II})$ removal $(\mathrm{mg} / \mathrm{L})$ 

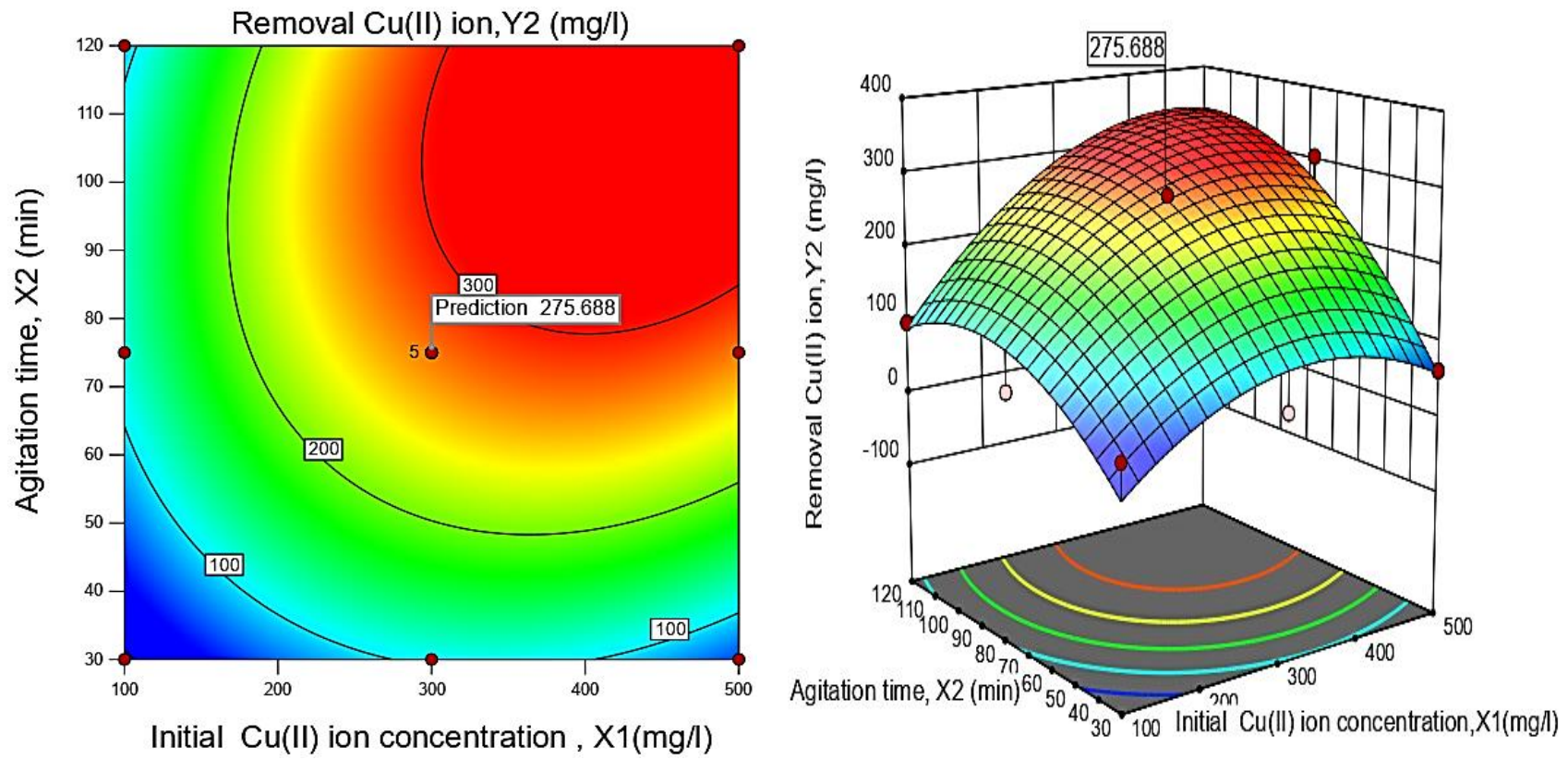

Fig. 2. The IB response surface contour and 3-D plots for the effect initial $\mathrm{Cu}(\mathrm{II})$ ions concentration and agitation time $(\mathrm{min})$ on $\mathrm{Cu}(\mathrm{II})$ removal $(\mathrm{mg} / \mathrm{L})$
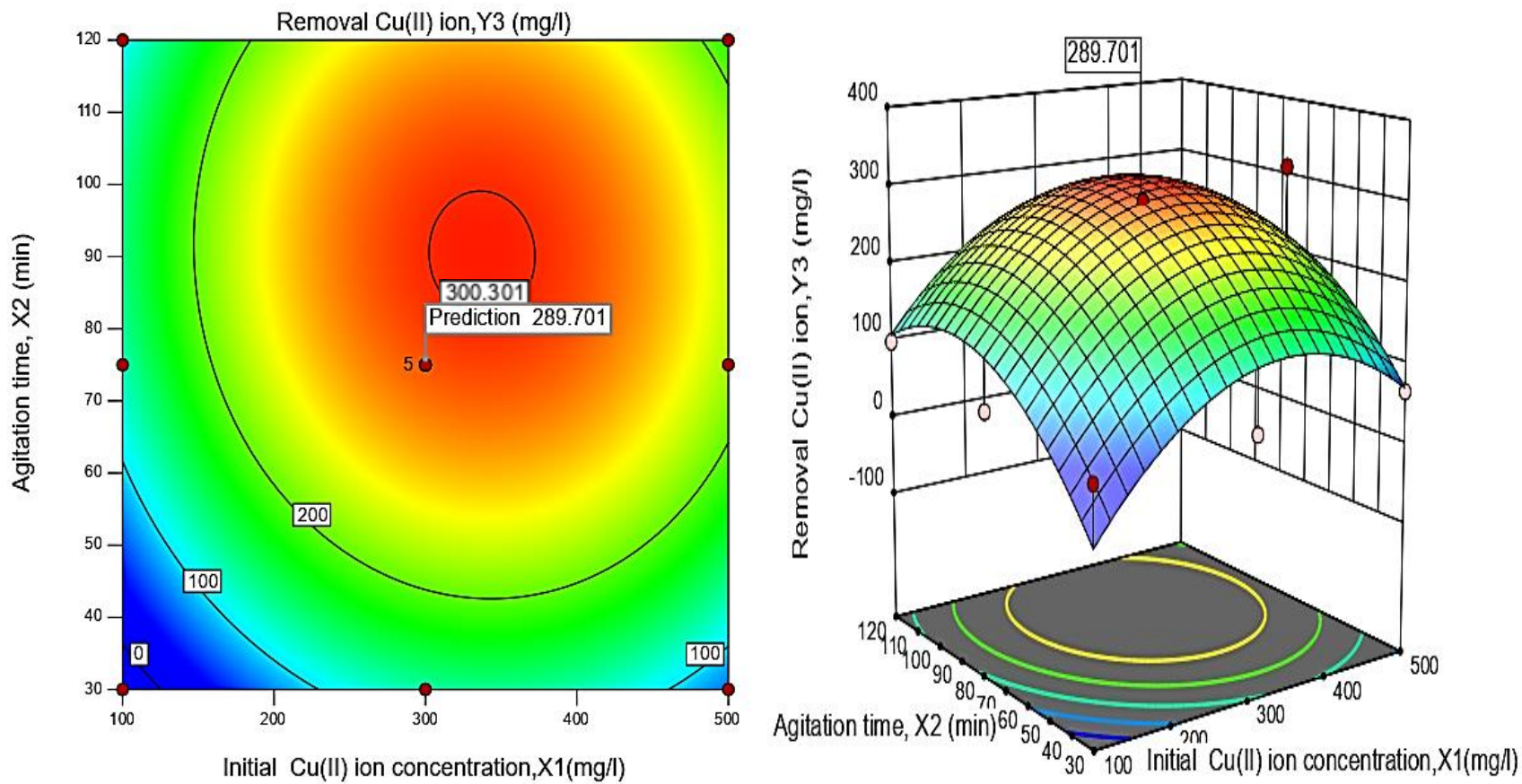

Fig. 3. The PB response surface contour and 3-D plots for the effect of initial $\mathrm{Cu}(\mathrm{II})$ ions concentration and agitation time $(\mathrm{min})$ on $\mathrm{Cu}(\mathrm{II})$ removal $(\mathrm{mg} / \mathrm{L})$ 


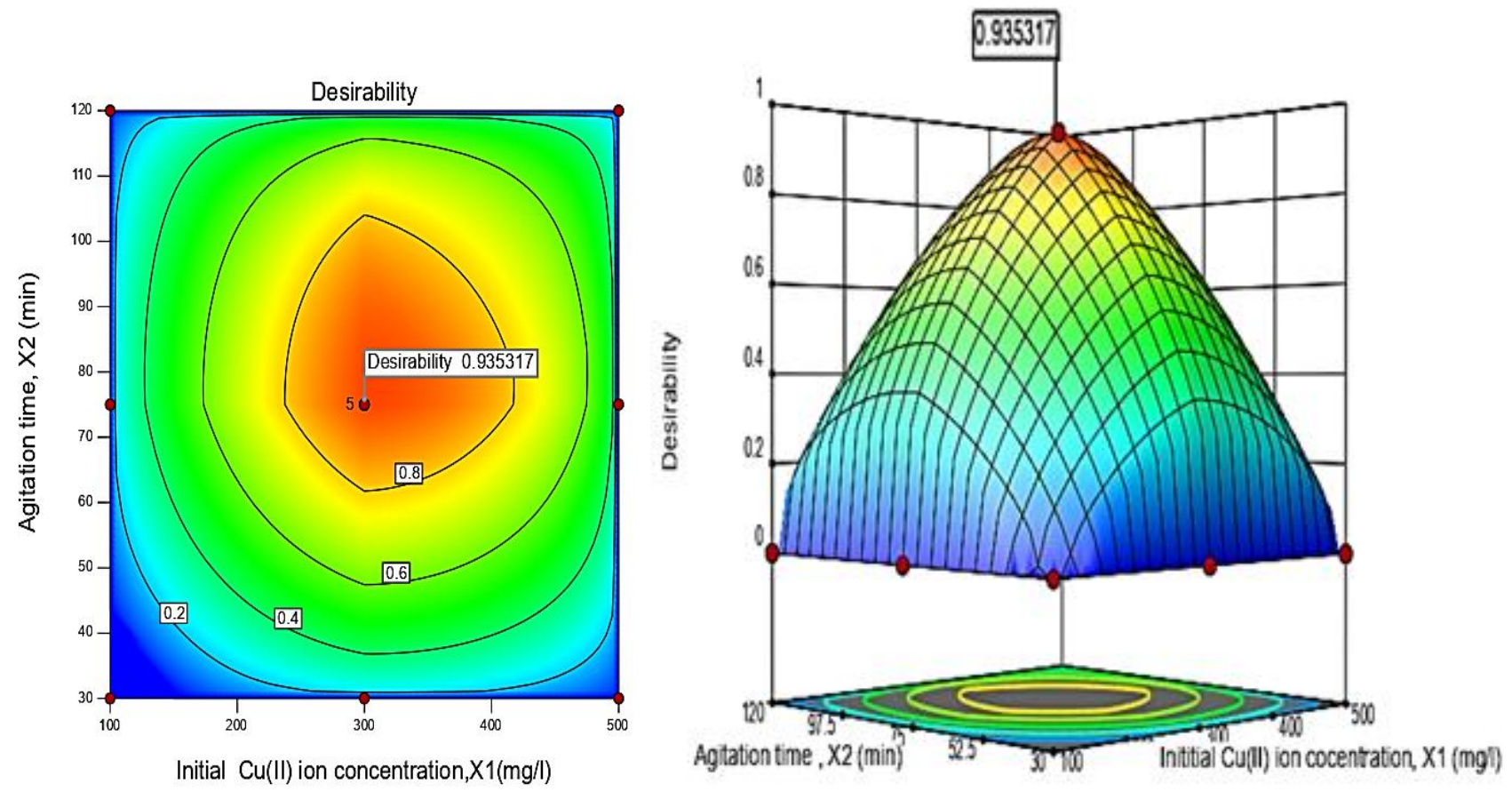

Fig. 4. Optimization Response surface contour and 3-D for desirability ramp plots for the effect initial $\mathrm{Cu}(\mathrm{II})$ ions concentration and agitation time $(\mathrm{min})$ on $\mathrm{Cu}(\mathrm{II})$ removal $(\mathrm{mg} / \mathrm{L})$

The interactive effect of any two of three independent factors on dependent factor were showed graphically by contour and 3-D response surface. Optimization using the desirability function was shown in Figure 5.
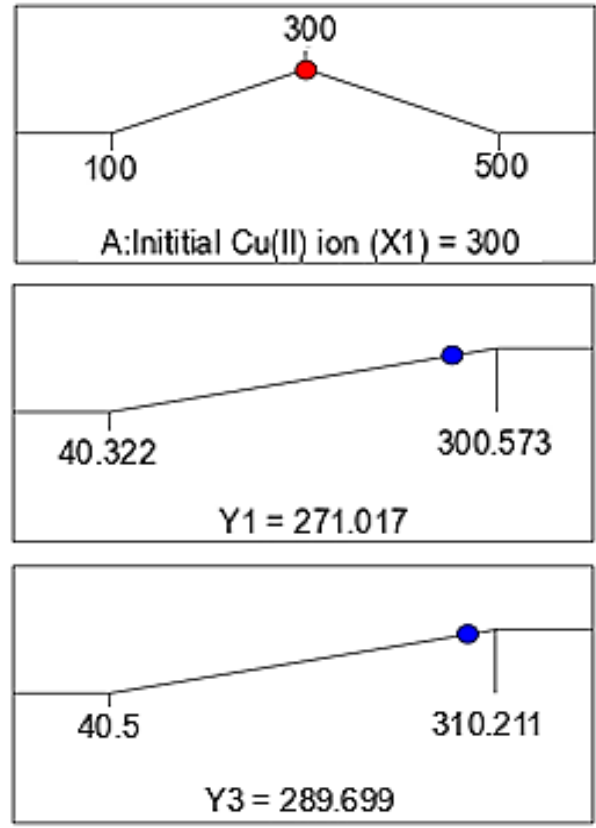
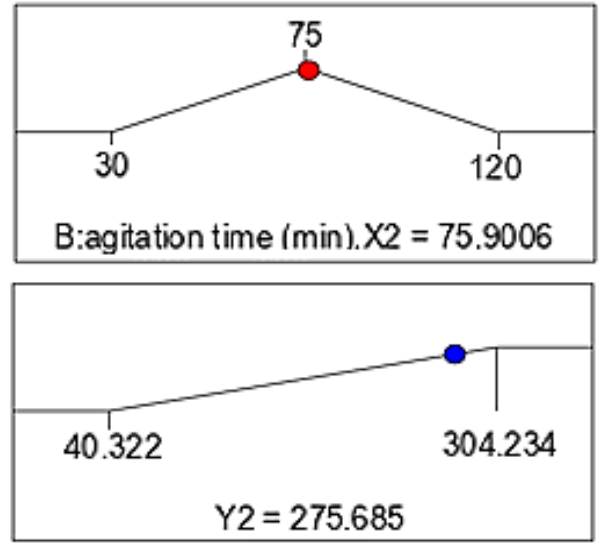

\section{Desirability $=0.935$} Solution 1 out of 3

Fig. 5. Desirability ramp for numerical optimization of two goals of independent variable i.e. the initial copper ion concentration and agitation time and copper removal as response variable 
Based on the numerical optimization, it was obtained that the maximum copper removal by the NB, IB and PB were 271.017, 275.685 and $289.699 \mathrm{mg} / \mathrm{L}$ respectively with initial copper concentration of $300 \mathrm{mg} / \mathrm{L}$ and agitation time of $75.901 \mathrm{~min}$. To obtain the $\mathrm{Cu}(\mathrm{II})$ adsorption capacity for each adsorbate at certain adsorption time, Eq. (7) can be used [33].

$$
q_{t=n}=\frac{\left(C_{t=0}-C_{t=n}\right) V_{S}}{m_{A C}}
$$

where $C_{t=0}(\mathrm{mg} / \mathrm{L})$ is $\mathrm{Cu}(\mathrm{II})$ ions concentration in liquid phase at the time of zero ( $t=0 \mathrm{~min}$ ), which is the $\mathrm{Cu}(\mathrm{II})$ initial concentration; $C_{t=n}(\mathrm{mg} / \mathrm{L})$ represents $\mathrm{Cu}(\mathrm{II})$ ions concentration in liquid phase at the time of $t=n(\mathrm{~min}) ; q_{t=n}(\mathrm{mg} / \mathrm{g})$ is the $\mathrm{Cu}(\mathrm{II})$ adsorption capacity of adsorbate used at a certain adsorption time of $t=n ; V_{S}(\mathrm{~L})$ is the batch mode of $\mathrm{Cu}(\mathrm{II})$ aqueous solution volume (L); and $m_{A C}(\mathrm{~g})$ denotes as the mass of adsorbate. The $\mathrm{Cu}(\mathrm{II})$ removal can be calculated using the expression of $C_{t=0}$ $C_{t=n}(\mathrm{mg} / \mathrm{L})$. Therefore, the maximum copper adsorption capacity of the NB, IB and PB were obtained to be approximately $27.101,27.568$ and $28.969 \mathrm{mg} / \mathrm{g}$ respectively.

\section{Conclusions}

From the results obtained, it can be summarized that natural bentonite, intercalate bentonite and pillared bentonite utilized were a promising adsorbate for copper removal in water treatment. Optimization of adsorption using by response surface methodology was success to obtain the maximum copper removal. The maximum copper removal by the PB being $289.699 \mathrm{mg} / \mathrm{L}$ was greater than by the NB and IB which were 271.017, $275.685 \mathrm{mg} / \mathrm{L}$ respectively. The maximum copper adsorption capacity of the NB, IB and PB were $27.101,27.568$ and $28.969 \mathrm{mg} / \mathrm{g}$ respectively with the optimum condition with initial copper concentration of $300 \mathrm{mg} / \mathrm{L}$ and agitation time of $75.901 \mathrm{~min}$.

\section{Acknowledgment}

The authors are grateful to Doctoral Program of Engineering Sciences and Chemical Engineering Department, Faculty of Engineering at Universitas Syiah Kuala for technical support.

\section{References}

[1] Hawkes, S.J. "What is a heavy metal?" Journal of Chemical Education 74, no. 11 (1997): 1374-1380. https://pubs.acs.org/doi/abs/10.1021/ed074p1374

[2] Clare, D'Souza, and Peretiatko Roman. "The nexus between industrialization and environment. A case study of Indian enterprises." Environmental Management and Health 13, no. 1 (2002): 80-97. https://doi.org/10.1108/09566160210417859

[3] Theophanides T., and J. Anastassopoulou. "Copper and carcinogenesis." Critical Reviews In Oncology/Hematology 42, no. 1 (2002): 57-64. https://doi.org/10.1016/S1040-8428(02)00007-0

[4] Kandah, Munther I., Fahmi A. Abu Al-Rub, and Naser Al-Dabaybeh. "The aqueous adsorption of copper and cadmium ions onto sheep manure." Adsorption Science \& Technology 21, no. 6 (2003): 501-509. https://doi.org/10.1260/026361703771953569

[5] Carl, L. Keen, J. Mcardle Harry, and M. W. Elizabeth. "A review: The impact of copper on human health." International Copper Association Ltd., New York (2003): 19.

[6] Gupta, Rani, Prerna Ahuja, Seema Khan, R. K. Saxena, and Harapriya Mohapatra. "Microbial biosorbents: meeting challenges of heavy metal pollution in aqueous solutions." Current Science 78 (2000): 967-973.

[7] Minamisawa, Mayumi, Hiroaki Minamisawa, Shoichiro Yoshida, and Nobuharu Takai. "Adsorption behavior of heavy metals on biomaterials." Journal of Agricultural and Food Chemistry 52, no. 18 (2004): 5606-5611. https://doi.org/10.1021/if0496402

[8] Srivastava, N. K., and C. B. Majumder. "Novel biofiltration methods for the treatment of heavy metals from 
industrial wastewater." Journal of Hazardous Materials 151, no. 1 (2008): 1-8.

https://doi.org/10.1016/i.jhazmat.2007.09.101

[9] Guo, Yan-Biao, Hong Feng, Chong Chen, Chong-Jian Jia, Fan Xiong, and Ying Lu. "Heavy Metal Concentrations in Soil and Agricultural Products Near an Industrial District." Polish Journal of Environmental Studies 22, no. 5 (2013): 13571362.

[10] Eccles, H. "Treatment of metal-contaminated wastes: why select a biological process?." Trends in Biotechnology 17, no. 12 (1999): 462-465.

https://doi.org/10.1016/S0167-7799(99)01381-5

[11] Tolonen, Emma-Tuulia, Arja Sarpola, Tao Hu, Jaakko Rämö, and Ulla Lassi. "Acid mine drainage treatment using byproducts from quicklime manufacturing as neutralization chemicals." Chemosphere 117 (2014): 419-424.

https://doi.org/10.1016/i.chemosphere.2014.07.090

[12] Kalhor, Mozhgan Moradi, Amir Abbas Rafati, Lida Rafati, and Amir Ali Rafati. "Synthesis, characterization and adsorption studies of amino functionalized silica nano hollow sphere as an efficient adsorbent for removal of imidacloprid pesticide." Journal of Molecular Liquids 266 (2018): 453-459.

https://doi.org/10.1016/j.molliq.2018.06.041

[13] Eslami, Hadi, Mohammad Hassan Ehrampoush, Abbas Esmaeili, Ali Asghar Ebrahimi, Mohammad Hossein Salmani, Mohammad Taghi Ghaneian, and Hossein Falahzadeh. "Efficient photocatalytic oxidation of arsenite from contaminated water by $\mathrm{Fe}_{2} \mathrm{O}_{3}-\mathrm{Mn}_{2} \mathrm{O}_{3}$ nanocomposite under UVA radiation and process optimization with experimental design." Chemosphere 207 (2018): 303-312. https://doi.org/10.1016/j.chemosphere.2018.05.106

[14] Motsi, T., N. A. Rowson, and M. J. H. Simmons. "Adsorption of heavy metals from acid mine drainage by natural zeolite." International Journal of Mineral Processing 92, no. 1-2 (2009): 42-48.

https://doi.org/10.1016/i.minpro.2009.02.005

[15] Wulandari, Dyah Arum, and Euis Djubaedah Nasruddin. "Selectivity of Water Adsorbent Characteristic on Natural Zeolite in Cooling Application." Journal of Advanced Research in Fluid Mechanics and Thermal Sciences 55, no. 1 (2019): 111-118.

[16] Sandy, V. Maramis, A. Kurniawan, A. Ayucitra, J. Sunarso, and S. Ismadji. "Removal of copper ions from aqueous solution by adsorption using LABORATORIES-modified bentonite (organo-bentonite)." Frontiers of Chemical Science and Engineering 6 (2012): 5-66.

https://doi.org/10.1007/s11705-011-1160-6

[17] Srinivasan, R. "Advances in Application of Natural Clay and Its Composites in Removal of Biological, Organic, and Inorganic Contaminants from Drinking Water." Advances in Materials Science and Engineering (2011): ID 872531. https://doi.org/10.1155/2011/872531

[18] Shuhada, N. H., N. A. Ahmad, and Z. Adzis. "Grounding Enhancement Material Using Bentonite." Journal of Advanced Research in Fluid Mechanics and Thermal Sciences 24, no. 1 (2016): 1-8.

[19] Belachew, N., and G. Bekele. "Synergy of Magnetite Intercalated Bentonite for Enhanced Adsorption of Congo Red Dye." Silicon 12, (2020): 603-612. https://doi.org/10.1007/s12633-019-00152-2

[20] Fadhila Ayari, Ghada Manai, Selma Khelifi, Malika Trabelsi-Ayadi. "Treatment of anionic dye aqueous solution using Ti, HDTMA and Al/Fe pillared bentonite. Essay to regenerate the adsorbent." Journal of Saudi Chemical Society 23, no. 3, (2019: 294-306.

https://doi.org/10.1016/j.jscs.2018.08.001

[21] Ronald A. Otavo-Loaiza, Nancy R. Sanabria-González, and Gloria I. Giraldo-Gómez. "Tartrazine Removal from Aqueous Solution by HDTMA-Br-Modified Colombian Bentonite." The Scientific World Journal (2019): ID 2042563. https://doi.org/10.1155/2019/2042563

[22] Tomul, F., F.T. Basoglu, and H/ Canbay. "Determination of adsorptive and catalytic properties of copper, silver and iron contain titanium-pillared bentonite for the removal bisphenol A from aqueous solution." Applied Surface Science 360, Part B (2016): 579-593.

https://doi.org/10.1016/i.apsusc.2015.10.228

[23] Manohar, D.M., B.F. Noeline, T.S. Anirudhan. "Adsorption performance of Al-pillared bentonite clay for the removal of cobalt(II) from aqueous phase." Applied Clay Science 31, no. 3-4 (2006): 194-206.

https://doi.org/10.1016/i.clay.2005.08.008

[24] Liang-guo Yan, Yuan-yuan Xu, Hai-qin Yu, Xiao-dong Xin, Qin Wei, Bin Du. "Adsorption of phosphate from aqueous solution by hydroxy-aluminum, hydroxy-iron and hydroxy-iron-aluminum pillared bentonites." Journal of Hazardous Materials 179, no. 1-3 (2010): 244-250. https://doi.org/10.1016/i.jhazmat.2010.02.086

[25] Ghiaci, M., R.J. Kalbasi, and A. Abbaspour. "Adsorption isotherms of non-ionic surfactants on Na-bentonite (Iran) 
and evaluation of thermodynamic parameters." Colloids and Surfaces A: Physicochemical and Engineering Aspects 297, no. 1-3 (2007): 105-113.

https://doi.org/10.1016/j.colsurfa.2006.10.032

[26] Müjde Altunlu, and Saadet Yapar. "Effect of $\mathrm{OH}-/ \mathrm{Al} 3+$ and $\mathrm{Al3}+/$ clay ratios on the adsorption properties of Alpillared bentonites." Colloids and Surfaces A: Physicochemical and Engineering Aspects 306, no. 1-3 (2007): 88-94. https://doi.org/10.1016/i.colsurfa.2006.10.071

[27] Julinawati, J., Gea, S., Eddiyanto, E., Wirjosentono, B., \& Ichwana, I. (2019, May). The use of bentonite of Bener Meriah Aceh to improve the mechanical properties of Polypropylene-Montmorillonite Nanocomposite. In IOP Conference Series: Materials Science and Engineering (Vol. 523, No. 1, p. 012023). IOP Publishing. https://doi.org/10.1088/1757-899X/523/1/012023

[28] Mohammed J.K. Bashir,Hamidi Abdul Aziz, Shuokr Qarani Aziz, and Salim Abu Amr. "An overview of Wastewater Treatment Processes Optimization Using Response Surface Methodology (RSM)." In The 4th International Engineering Conference-Towards engineering of 21st century, 1-11, 2012.

[29] Nor Azimah Ahmad, Mohd Ariffin Abu Hassan, Zainura Zainon Noor, Abdullahi Mohammed Evuti, Jibrin Mohammed Danlami. "Optimization of Nickel Removal from Electroless Plating Industry Wastewater using Response Surface Methodology." Jurnal Teknologi (Sciences and Engineering) 67, no. 4, (2014): 33-40. https://doi.org/10.11113/it.v67.2789

[30] Huayue Zhu, ongqian Fu, Ru Jiang, Jun Yao, Ling Xiao, Guangming Zeng. "Optimization of Copper(II) Adsorption onto Novel Magnetic Calcium Alginate/Maghemite Hydrogel Beads Using Response Surface Methodology." Industrial \& Engineering Chemistry Research 53, no. 10 (2014): 4059-4066. https://doi.org/10.1021/ie4031677

[31] Muslim, Abrar, Marwan, Ramli Saifullah, Muhammad Yahya Azwar, Darmadi, Bayu Pramana Putra, and Samsul Rizal. "Adsorption of $\mathrm{Cu}(\mathrm{II})$ ionss on Areca Catechu Stem-Based Activated Carbon: Optimization Using Response Surface Methodology." International Review on Modelling and Simulations 12, no. 2 (2019): $123-129$. https://doi.org/10.15866/iremos.v12i2.16846

[32] Amir Sheikhmohammadia, Seyed Mohsen Mohsenib, Bayram Hashemzadeha, Esrafil Asgaria, Rahim Sharafkhania, Mahdieh Sardarb, Maryam Sarkhoshc, and Mohammad Almasianed. "Fabrication of magnetic graphene oxide nanocomposites functionalized with a novel chelating ligand for the removal of $\mathrm{Cr}(\mathrm{VI})$ : Modeling, optimization, and adsorption studies." Desalination and water treatment 160 (2019): 297-307.

https://doi.org/10.5004/dwt.2019.24381

[33] Abrar Muslim, Husni Husin, Saifullah Ramli, Akhyar Irfan, Firdaus, 2016, Adsorption of Pb(II) in Aqueous Solutions by Activated Carbon Prepared From Empty Fruit Bunch of Oil Palm, The Collaboration and Contribution of Islam, Science and Technology for ASEAN Economic Community, The 7th International Conference on Green Technology, Malang, 5-6 October 2016, Malang, Faculty of Science and Technology, Maulana Malik Ibrahim State Islamic University, 2301-4490. 